\title{
Apprentices' Errors in Intrapreneurship: Findings from a Large-Scale Assessment
}

\author{
Christine Kreuzer $^{1} \cdot$ Susanne Weber ${ }^{1}$
}

Received: 24 January 2019 / Accepted: 7 January 2020 / Published online: 22 February 2020

(C) The Author(s) 2020

\begin{abstract}
Intrapreneurship competence, as one of the main twenty-first century skills, has moved into focus, as it enables benefits for both organizations and individuals. To foster associated competencies and enable tailor-made instruction, teachers need knowledge not only about what their students can do but also about which errors are typically made within this domain. To identify such knowledge, we analyzed the results from a largescale assessment (5436 responses). We then classified the errors found according to more overarching error categories and assigned them to the facets of a previously developed and validated intrapreneurship competence model to obtain a deeper understanding of which facets of intrapreneurship are not mastered and what the problems are. Additionally, we refer to more general error types in the domain of creative problem-solving to integrate our findings into the broader discussion. By formulating this error-related information as domain-specific negative knowledge, which refers to "how something is not" or "how something does not work", respectively, we can use this information constructively when designing instructional means for future tailormade approaches and individual guidance.
\end{abstract}

Keywords Intrapreneurship competence $\cdot$ Creative problem-solving $\cdot$ Errors $\cdot$ Negative knowledge

\section{Introduction}

Entrepreneurial behaviors like problem construction, information gathering, concept selection, conceptual combination, idea generation, idea evaluation, implementation planning, and monitoring (also known as creative problem-solving; Mumford et al. 2006) are becoming increasingly important for individuals of all vocational types

Susanne Weber

susanne.weber@bwl.lmu.de

1 Institut für Wirtschaftspädagogik, Ludwig-Maximilians-Universität München, Ludwigstr. 28 RG/ III, 80539 München, Germany 
(Bosma et al. 2013). This is substantiated by international findings such as the Global Entrepreneurship Monitor results, which show that those behaviors can be observed by both independent entrepreneurs and entrepreneurs within a firm (also known as corporate entrepreneurs, or intrapreneurs; Antoncic and Hisrich 2001) in increasing numbers all around the world (Bosma and Kelley 2018; Bosma et al. 2013). Additionally, such entrepreneurial behavior takes on special relevance with regard to the dynamics of workplace affordances caused by digitalization, as many routines are automated, and new work procedures must be created or modified (Harteis 2018). Also, educational frameworks address these demands - using different labels including “innovative behavior" (Messmann and Mulder 2017), "proactivity" (Eteläpelto et al. 2013), or intrapreneurship competence as a manifestation of work agency (WietheKörprich et al. 2017). For example, the European Union [EU] describes associated abilities such as "sense of initiative and entrepreneurship" as key competencies for lifelong learning that are needed by every individual of a knowledge-driven society (Bacigalupo et al. 2016; EU 2006). Possessing those capacities is beneficial for individuals' development in private life, and for ensuring their employability (Baggen et al. 2016; Bacigalupo et al. 2016; Weber et al. 2014). Therefore, one reason for organizations to foster intrapreneurship is the demand to stay competitive in a globalized world (Borza and Maier 2012). Employees' innovative and intrapreneurship behavior can be a key success factor in meeting this demand.

In innovation-driven countries such as Germany, the prevalence of entrepreneurial behavior is $7.6 \%$, which is higher than the international mean value $(6.5 \%$; Bosma et al. 2013). In the literature, we find abundant evidence that intrapreneurial abilities can be learned and developed across different age groups (Bacigalupo et al. 2016; Graevenitz et al. 2010). In our study, we focus on apprentices, as empirical findings show a high potential of entre- and intrapreneurship among adolescents and young adults (e.g., Frank et al. 2016; Rauch and Hulsink 2015; Volery et al. 2013) and underline a reasonable impact of apprentices on organizational innovations (Backes-Gellner and Rupietta 2014). As nearly half of the youth in Germany are entering the dual apprenticeship system for an educational program, a focus on this appears to be further promoted (Federal Statistical Office [Destatis] \& Berlin Social Science Research Center Berlin [WZB] 2018). Teaching intrapreneurship behavior is highly domain-specific, which is why we focus on the domain of "business" and in particular on the subarea of "industry" for the field of industrial clerks and the apprenticeship of industrial clerks. This commercial apprenticeship program has been one of the most frequently chosen programs in Germany for many years (German Federal Ministry for Education and Research [BMBF] 2019). At the same time, it is classified as a cross-sectional occupation, as it has decisive curricular overlaps with several other highly chosen apprenticeship programs in Germany (Baethge et al. 2008; Deutscher and Winther 2017). Furthermore, the international comparative study on workplace affordances and required competencies of Breuer et al. (2009) shows similarities between the occupation of German industrial clerks and several international commercial workplace settings such as within the fields of sales and marketing or purchasing - work areas and associated jobs that do not just include routinized work.

However, the effective realization of intrapreneurship processes is difficult and demanding — not just for apprentices - as these processes require a high amount of attention and the application of different heuristics and strategies that are sometimes 
contradictory (e.g., whereas a certain amount of information is necessary, the search for this amount of information might appear to be a sufficient solution) (Mumford et al. 2006). This means that many errors can occur during this process of creative problemsolving and entre/intrapreneurship behavior. Although errors could be a promising starting point of innovation, they could also inhibit innovation processes (Hammond and Farr 2011; Mumford et al. 2006). As there is, to our knowledge, no information about errors made by apprentices in realizing intrapreneurship in the field of industrial clerk apprentices, we need more empirically valid and reliable insights (Hammond and Farr 2011) to foster intrapreneurship. We need the domain-specific content to identify errors, to describe them, and to associate them to more overarching error types (e.g., the 35 error types formulated for the creative problem-solving; Mumford et al. 2006). By this abstraction procedure, we may transfer our results into other intrapreneurshiprelated contexts. This procedure of "casuistic-systematic" or "concrete-abstract-reconcrete" (Achtenhagen 2001) is used for linking the domain-specific with the more general discussion.

Such insights could subsequently enable the tailor-made guidance of apprentices (Hattie 2012) and provide important feedback for teachers and researchers. The errors found can be used as additional learning possibilities (in the sense of "learning from errors"; Bauer et al. 2012; Grohnert et al. 2018; Oser and Spychiger 2005; Seifried and Wuttke 2010; Weingardt 2004), enhance the reflection on the content to be learned (Bauer et al. 2012), and help the apprentices avoid the same mistakes within their future entre/intrapreneurial behavior at their workplaces (in the sense of "negative knowledge"; Oser and Volery 2012). However, errors and knowledge about them are always domain-specific (Cattaneo and Boldrini 2017; Seifried and Wuttke 2012; Türling et al. 2011; Weingardt 2004).

The goal of this study is to analyze apprentices' errors in observed intrapreneurship behavior in the domain of business and industry, and in particular within typical occupational work settings occurring in daily life in the industrial clerks' apprenticeship. Therefore, we run an in-depth analysis of a scientific use file of a large-scale assessment (LSA) (Winther et al. 2017). We use a data set that fits the main quality criteria: objectivity (e.g., large samples of comparable information), reliability (e.g., empirically justified trustworthiness of the instrument), and validity (e.g., empirical evidence of the correct illustration of the evaluated construct) (Darling-Hammond et al. 2013; Shavelson 2010).

Within our study, we follow an explorative approach and comprehensively analyze apprentices' responses on six open-format tasks of the LSA that represent typical intrapreneurship challenges an industrial clerk apprentice is faced with (906 apprentices resulting in $N=5436$ answers). By conducting an inductive content analysis (Mayring 2015) and a subsequent frequency analysis, we identify common errors regarding commercial intrapreneurship of industrial clerk apprentices (RQ1). In a further step, we link these identified domain-specific errors for content-didactical considerations to prior defined skill bundles identified in separate studies (incl. think alouds and expert ratings) as relevant for successfully solving the particular tasks (cf. Bley 2017; George et al. 2019; Weber et al. 2016; Wiethe-Körprich et al. 2017). In an additional step, we associate the errors found to the more general error types of Mumford et al. (2006) to connect our findings to an overarching discussion (RQ2). Within our discussion, we refer to our findings and show how they could be used to develop tailor-made guidance 
to enhance the teaching of competent intrapreneurship behavior in the sense of intrapreneurship competence (Hattie 2012).

In the following, the theoretical background is presented regarding (a) the construct of intrapreneurship and intrapreneurship competence operationalized in the context of industrial clerks' apprenticeship and (b) errors and the need for a domain-specific identification. Subsequently, a methodological chapter provides insights into the data used, the coding procedure, and further analysis. The results are presented, followed by a discussion on how knowledge about those identified errors could be used for a targeted instruction, limitations, and future prospects.

\section{Theoretical Background}

\section{Operationalizing Intrapreneurship and Intrapreneurship Competence}

Overall, intrapreneurship is understood as entrepreneurship within existing organizations (Antoncic and Hisrich 2001). Following an approach at the individual level, employees show proactive efforts resulting in "out-of-the-box" thinking within bottomup processes (Bosma and Kelley 2018; Bosma et al. 2013; Moriano et al. 2014; Pinchot 1985; Wiethe-Körprich et al. 2017). This creative work behavior focuses on the generation and implementation of both incremental and radical innovations (de Jong and Marsili 2015; Messmann and Mulder 2017). As a result, benefits are generated for the organizations and the individual employees (Borza and Maier 2012; Corbett et al. 2013; Ireland et al. 2009; Kuratko 2009; Kuratko et al. 2019; Short et al. 2010). Considering the intrapreneurial process, associated evidentiary behaviors as well as outputs are highly domain-specific. Nevertheless, two aspects of the intrapreneurial process can be identified across all domains: the perception of innovation potentials (known as opportunity recognition) and action on these innovation potentials within projects (known as opportunity realization) (Bosma et al. 2013; Frank et al. 2016; Pinchot 1985). To manage those processes, various attributes are associated with intrapreneurs. Referring to opportunity recognition, characteristics such as risk-taking propensity (Boon et al. 2013) and openness (Madrid et al. 2014) are formulated. Regarding the implementation of those innovations, personal initiative (Frese and Fay 2001) and resilience (Carmelo-Ordaz et al. 2012) against organizational barriers appear to be especially important. Intrapreneurs are triggered by situational challenges arising through changes (e.g., technological developments; Shane 2000; Kuratko et al. 2005), challenges (e.g., market threats; Kuratko et al. 2019), or problems (e.g., errors; Hammond and Farr 2011), and act with the (if necessary, newly acquired) resources of and within complex bureaucracies (Perlman et al. 1988).

Considering competent intrapreneurship behavior as a learnable competence, such behavior comprises latent cognitive dispositions (referring to knowledge and skills) and affective-motivational facets (known as attitudes), which are both realized within directly observable situation-specific performance (Blömeke et al. 2015; Mulder and Winterton 2017). Taking the perspective of workplace learning, Weber et al. (2014, 2016) and Wiethe-Körprich et al. (2017) introduced an intrapreneurship competence model for apprentices to link situational challenges that industrial clerks have to cope with in their daily work, on the one hand, with intrapreneurs' attributes, on the other 
hand, resulting in an observable intrapreneurial performance for the context of commercial apprenticeship. According to this model, individual intrapreneurs are faced with situational challenges, such as (1) perceiving opportunities and risks, (2) generating innovative business ideas, (3) planning a project by means of a time schedule, (4) anticipating and estimating risks, (5) planning and monitoring costs and profits, and (6) coping with disturbances. To master such situational challenges, situation-specific skills (competencies) are necessary, for example "analyzing intrapreneurship situations (ANAL)", or "using creativity techniques (CREA)" (Fig. 1). Additionally, for content-didactical consideration, the project group developed a researcher construction matrix and validated within further studies bundles of skills that are necessary for solving intrapreneurial tasks successfully (cf. Bley 2017; George et al. 2019; Weber et al. 2016; Wiethe-Körprich et al. 2017). Regarding empirical findings, there are hints that the situational challenges associated with opportunity recognition are more difficult to face than those of opportunity realization (Weber et al. 2016).

\section{Operationalizing Errors}

When applying these situation-specific skills, various errors can occur. There is much literature on how to define and understand errors (cf. Weingardt 2004). Referring to action regulation theory (Frese and Zapf 1994; Hacker 1986, 2005; Volpert 1992), the theoretical base holds the chance to define errors and describe a typology of errors at the same time. Therefore, errors are goal-oriented actions (Frese and Zapf 1994; Bauer 2008) that deviate unintentionally from a set norm (Bauer and Harteis 2012; Frese and Zapf 1994; Hofmann and Frese 2011; Oser and Spychiger 2005). Errors could impede successful performance (Hofmann and Frese 2011). Nevertheless, errors also hold the chance of positive outputs and can be the starting point of learning and innovation processes (Hammond and Farr 2011; Gartmeier and Schüttelkopf 2012; Gartmeier and Winkler 2015). An error always holds an evaluative component because it comes only into existence when there is an a priori set norm (e.g., goal) that an action can deviate

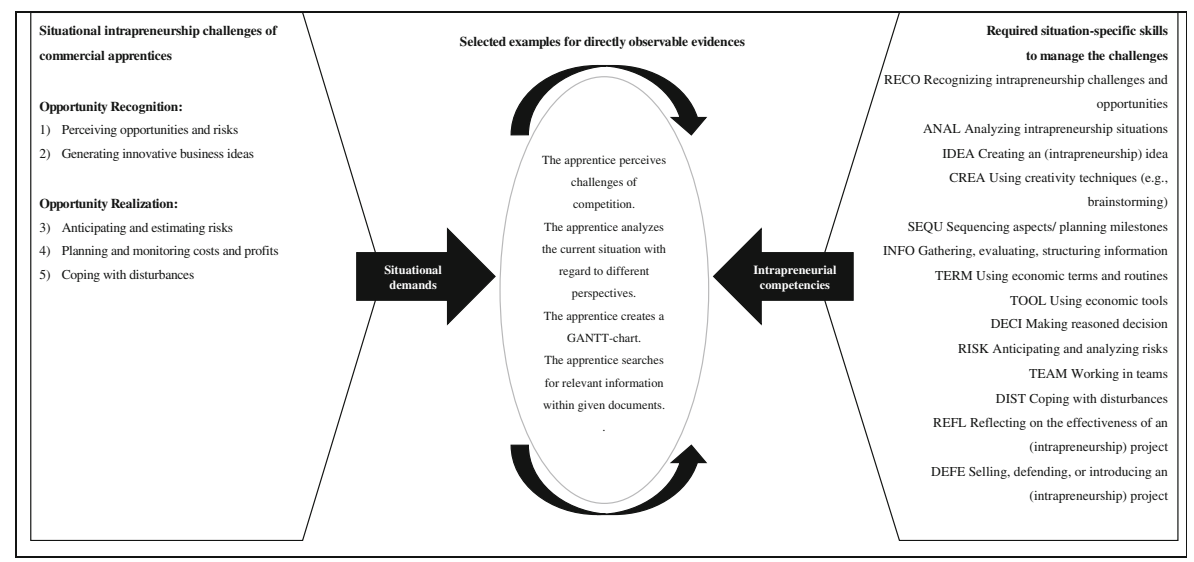

Fig. 1 Overview of the interplay of situational demands (situational intrapreneurship challenges) and intrapreneurial competencies (situation-specific skills) of commercial apprentices. Adapted from Bley (2017), Weber et al. (2016), Weiß and Weber (2016), and Wiethe-Körprich et al. (2017) 
from (Frese and Zapf 1994; Heid 2015; Hofmann and Frese 2011; Oser and Spychiger 2005). Different norms are possible, whereas we refer to an objective norm (comparison to an a priori set of performance norms) (Weingardt 2004).

Regarding the cognitive structure of an action, action regulation theory (Frese and Zapf 1994; Hacker 1986, 2005; Volpert 1992) also helps establish an error taxonomy. This is necessary because different types of errors demand different reactions (e.g., teaching-learning methods; Bauer 2008; Helmreich 2000). In general, an error is regarded as something that can be attributed to an individual, as he/she possesses sufficient knowledge (Bauer et al. 2010). To appear as wrong, the underlying mental model (in the sense of a knowledge base) is assumed to be fragmented or applied in a faulty way (Bauer et al. 2010). This application results in a good plan that is badly executed or a mistaken plan (Senders and Moray 1991). Regarding the cognitive execution level, a differentiation between slips and lapses and rule- and knowledgebased errors is formulated (Rasmussen 1987a). As the latter are especially open to deliberate training (Bauer 2008), we concentrate on these. Furthermore, slips and lapses do not qualify as errors, as they happen accidentally (Bauer and Mulder 2007; Harteis et al. 2008, 2012; Rasmussen 1987b; Rausch 2012; Reason 1987; Senders and Moray 1991; Weingardt 2004). Rule-based errors address the faulty use of if-then rules and other procedural aspects of a process (Weingardt 2004). They involve, for example, the misinterpretation of a situation (Bauer 2008). Therefore, conscious action is possible but not necessarily present (Bauer 2008; Hacker 1986). Knowledge-based errors characterize deviant conscious actions, such as decision-making or problem-solving (Bauer 2008). They are conceptualized with regard to a fragmented knowledge base (e.g., due to wrong reasoning; Bauer 2008) and result in faulty problem solutions within novel situations (Weingardt 2004). Altogether, knowledge- and rule-based errors address procedural or declarative knowledge (Anselmann and Mulder 2018).

Referring to objective norms, they are highly domain-specific (Wuttke and Seifried 2012; Seifried et al. 2010), as it is only by domain-specific identification and definition that an action can be evaluated as deviating and, therefore, as an error (Frese and Keith 2015; Gartmeier et al. 2015; Goodman et al. 2011). Nevertheless, research on errors is scarce for workplace learning in business and commerce. There are only a few exceptions, e.g., accounting (Seifried and Wuttke 2010; Türling et al. 2011) or general economic education (Aprea 2013; Minnameier 2008). A systematic analysis of learners' errors in intrapreneurship in general, and of commercial apprentices in particular, is entirely lacking. What can be found for the domain of innovative and creative thinking is a comprehensive overview of error types at an individual level (Mumford et al. 2006; Hammond and Farr 2011). Overall, 35 error types and their cognitive origin are described and linked to processes of creative problem-solving (e.g., the error type "information accessibility (\#11),", where only directly available information that is related to the processes of information gathering and problem construction is considered; the error type "isolation (\#21)", the differentiation of a situation into various subparts that do not allow for the observation of the relationships among them, which might affect the processes of idea generation and the planning of implementation; and the error type "anchoring (\#27)", or adherence to an original goal although new information is available, is related to processes of idea generation and evaluation; Mumford et al. 2006). Nevertheless, these findings are abstract rather than domainspecific, so there is need to identify typical errors in innovation processes and 
intrapreneurship behavior (Hammond and Farr 2011). As we refer to apprentices at the end of their apprenticeship program, we assume that deficient actions can be attributed and, therefore, qualified as rule- or knowledge-based errors. A conceptual and empirical differentiation of the two is hard, as rules are part of an individual's knowledge base (Bauer 2008; Bauer and Mulder 2007). Nevertheless, we refer to this differentiation and link the errors found in intrapreneurship behavior to the 35 error types of creative and innovative thinking (Mumford et al. 2006).

Building on the findings above, we formulate the following research questions for this study:

RQ1: Which domain-specific errors can be identified within commercial apprentices' intrapreneurship behavior in the field of industrial clerks?

RQ2: How can the identified errors be associated to the skill bundles relevant for solving the specific task successfully (cf. Bley 2017; George et al. 2019; Weber et al. 2016; Wiethe-Körprich et al. 2017), as well as to the 35 error types formulated for creative problem-solving (Mumford et al. 2006)?

\section{Method}

\section{Data Source, Instrument, and Background of Data Collection}

For our analysis, we use a dataset from the LSA on intrapreneurship competence of commercial apprentices called "ALUSIM" (Achtenhagen and Winther 2014; Weber et al. 2016; Winther and Achtenhagen 2009; Winther et al. 2017). The data originate from a Germany-wide study with 906 apprentices at the end of their three-year apprenticeship program. The data were collected in 28 vocational schools in seven federal states across Germany by a testlet design. The sample size was calculated by a power analysis (Draxler 2010). The resulting sample corresponds with regard to age, educational background, and gender to the annual governmental reporting for this apprenticeship program (BMBF 2019; Weber et al. 2016). Within this LSA, the apprentices have to work at a simulated enterprise, ALUSIM, which is integrated in a technology-based environment (originally developed by Achtenhagen and Winther 2009, 2014; Sangmeister et al. 2018; extended for intrapreneurship tasks within the research project of Weber et al. 2014, 2016), on 19 action-oriented intrapreneurship tasks (e.g., evaluating a given problem situation, generating new ideas for attracting new apprentices for the firm, creating a GANTT chart, calculating a break-even point, dealing with disturbances), operationalized by 49 items. These are presented within two authentic scenarios. The first scenario addresses the lack of qualified potential applicants in the apprenticeship labor market, and the second scenario addresses the introduction of a new distribution channel (online shop) for smartphone back covers and bumpers made of aluminum. Therefore, the first scenario focuses on typical situational intrapreneurship challenges regarding opportunity recognition. The second scenario concentrates on challenges that arise through opportunity realization (Fig. 1). The task formats range from multiple choices, assignment tasks, and calculations up to open formats. To underline the authentic real-world characteristics, the simulation includes video clips of the enterprise's history, explanation clips for introducing the 
products, and snapshots of employees' working situations. As in case studies, the apprentices are invited to take the role of a particular employee and to solve work tasks and problems. Figure 2 provides an example concerning task 5.

Here, the apprentice receives the task via email (1). Often, the apprentice has to consider additional information attached to the email (2) (here, two given calculations). The tasks can have closed or open formats (3). To work on the task, the apprentices can use familiar office tools such as table programs, an email program, or a calculator (4). The actions and responses are tracked and filed. The tasks were designed based on a domain analysis (e.g., current examinations, see Weber et al. 2014; Weber and Achtenhagen 2017) and were validated by experts in the field (vocational school teachers and trainers of the training firms). In addition, enterprises advertise such innovative project work on their website and post it in a firm journal to be recognized as an attractive employer.

Within the LSA, the data are analyzed by item response measures according to the theoretically designed competence model. The quality of the measurement regarding innovative behavior can be judged as good, as the results support the assumed twodimensional model of intrapreneurship competence (Weber et al. 2016). The scale reliability lies above .80 , and several checks (including a replication study; Weber et al. 2016), think aloud studies (Bley 2017; Bley et al. 2015; George et al. 2019), and studies of known group comparison (Kreuzer et al. 2017) show the validity of the designed tasks.

Going beyond an estimation of more simple or more difficult tasks and the probability of solving such tasks, in this study we identify apprentices' errors and error types by analyzing the responses to six open-format tasks completed within the abovedescribed LSA. For the six open-format tasks, we obtained 5436 responses from the 906 apprentices documented in the scientific use file (Winther et al. 2017; Weber et al. 2016). We judge this data set as a strong and fruitful basis for this endeavor because it is not just an ad hoc sample working on unstandardized tasks (Darling-Hammond et al. 2013; Shavelson 2010). The six open-format tasks are representative of the abovementioned intrapreneurship challenges because they refer to the situational
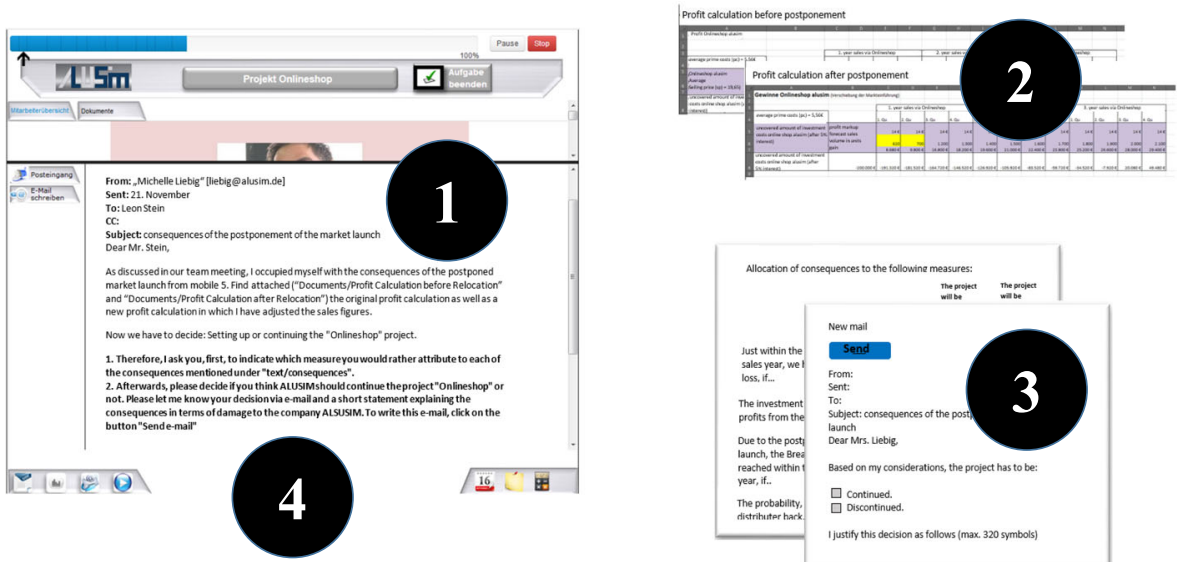

Fig. 2 Screenshots from the simulated enterprise workplace at ALUSIM 
intrapreneurship challenges of opportunity recognition and opportunity realization industrial clerks have to cope with (Fig. 1).

In Table 1, we provide an overview of the six analyzed tasks, including situational intrapreneurship challenges (task and task description). Referring to RQ1, the expected solution space understood as a set objective norm is included in the third column. Considering RQ2, the assumed situation-specific skills relevant for solving the tasks (Fig. 1) are integrated (column 4). Additionally, we include the associated error types according to Mumford et al. (2006) that can arise within these processes (column 5). The basis for this association was the researchers' construction matrix and prior studies of the project team (cf. Bley 2017; George et al. 2019; Weber et al. 2016; WietheKörprich et al. 2017). In a next step, the conceptualization of the 35 error types formulated by Mumford et al. (2006) was considered. They described the error types in more detail and associated them to specific problem-solving processes. For example, the error type \#2 "surface evaluation" looks for errors due to "overt similarities with past experience lead people to discount unique aspects of the situation that would call for the generation of new ideas" and effects "problem construction" as well as "idea evaluation" of the creative problem-solving process (Mumford et al. 2006, p. 95). Referring to this description and to effected processes, the following intrapreneurial skills are associated: RECO (recognizing intrapreneurship challenges and opportunities), ANAL (analyzing intrapreneurship situations), RISK (anticipating and analyzing risks), and REFL (reflecting on the effectiveness of an (intrapreneurship) project; Fig. 1). Lastly, we look for the tasks and where those skills are relevant for solving the tasks (column 4) to include the error type \#2 as a possibly arising error type within the specific task.

With regard to the results of the LSA, the six selected open-format tasks are characterized from medium to high difficulty compared to the mean of all task difficulties of the addressed situational intrapreneurship challenge within the LSA. In particular, the tasks can be described as shown in Table 2.

\section{Coding and Analysis}

We coded every response deviating from the a priori set objective norm (see Table 1, column 3) as an error. For example, in task 5, the apprentices have to decide whether the project should be implemented or not considering a given cost structure. The expected solution space (objective norm) suggests, based on the completed breakeven analysis, that the project can be implemented, as it reaches break-even within 2.5 years. An apprentice responded by stating "unfortunately, the analysis yielded the result that we should not implement the project (participant 108)". This deviation was coded as an error (Table 3). For RQ1 - identifying apprentices' domain-specific errors in intrapreneurship behavior-we searched inductively for key terms and condensed them by building overarching error categories (Mayring 2015) such as faulty intrapreneurial awareness, lacking tailored/evidence-based argumentation, and faulty use of economic/commercial routines/tools. For inductive coding, a recoding procedure for the material was run whenever a new category was found. All units were coded by two coders (Cohen's kappa $K=.829$ ). Multiple codings were possible (Rebmann 1996). Before further analysis took place, deviating codings were validated by consensus (Eisner 1991). 
Table 1 Overview of analyzed intrapreneurship tasks from the LSA

Situational intrapreneurship challenges among commercial apprentices

Task
Task description

\section{Observable evidence when solving the tasks (response)}

Referring to RQ1:

Expected solution space (objective norms set)
Situation- Possible error types specific according to Mumford skills* et al. 2006**

(Fig. 1)

Referring to RQ2

Curricular Which of the 35 error goals types could occur, in general?

\begin{tabular}{|c|c|c|c|c|}
\hline $\begin{array}{l}\text { Task 1: } \\
\text { Perceiving } \\
\text { opportuni- } \\
\text { ties and } \\
\text { risks }\end{array}$ & $\begin{array}{l}\text { Within the daily press, a } \\
\text { lack of skilled } \\
\text { potential applicants for } \\
\text { an apprenticeship } \\
\text { program is discussed. } \\
\text { The participant has to } \\
\text { perceive the imbalance } \\
\text { of supply and demand } \\
\text { in the Vocational } \\
\text { Education and } \\
\text { Training (VET) labor } \\
\text { market by means of } \\
\text { perspective taking. }\end{array}$ & $\begin{array}{l}\text { The participant considers } \\
\text { both the perspective of } \\
\text { a potential applicant } \\
\text { and the perspective of } \\
\text { ALUSIM and } \\
\text { formulates an } \\
\text { adequate statement. } \\
\text { Perspective of potential } \\
\text { applicant (future } \\
\text { apprentice): This } \\
\text { situation means that } \\
\text { applicants can choose } \\
\text { from a variety of } \\
\text { apprenticeship job } \\
\text { offers. } \\
\text { Perspective of ALUSIM: } \\
\text { This situation means } \\
\text { an increasing } \\
\text { competition for } \\
\text { potential applicants in } \\
\text { the VET labor market. }\end{array}$ & $\begin{array}{c}\text { RECO, } \\
\text { ANAL, } \\
\text { TERM }\end{array}$ & $\begin{array}{c}\# 1, \# 2, \# 3, \# 4, \# 5, \# 8, \# 9 \text {, } \\
\# 10, \# 11, \# 12, \# 13 \#, \\
\# 14 \#, \# 15, \# 16, \# 17, \\
\# 18, \# 19, \# 21, \# 22, \\
\# 23, \# 28 . \# 31, \# 32, \\
\# 33, \# 34\end{array}$ \\
\hline $\begin{array}{l}\text { Task 2: } \\
\quad \text { Generating } \\
\text { innovative } \\
\text { business } \\
\text { ideas }\end{array}$ & $\begin{array}{l}\text { ALUSIM assumes the } \\
\text { lack of skilled } \\
\text { potential applicants for } \\
\text { an apprenticeship } \\
\text { program as relevant. } \\
\text { Therefore, the } \\
\text { organization decides to } \\
\text { brainstorm as many } \\
\text { Human Resource } \\
\text { measures as possible } \\
\text { to recruit potential } \\
\text { apprentices in the VET } \\
\text { labor market. One } \\
\text { measure is given as an } \\
\text { example. }\end{array}$ & $\begin{array}{l}\text { Within } 2 \text { min, the } \\
\text { participant brainstorms } \\
\text { at least five Human } \\
\text { Resource measures. }\end{array}$ & IDEA & $\begin{array}{l}\# 15, \# 16, \# 17, \# 18, \# 20, \\
\quad \# 21, \# 22, \# 23, \# 24, \\
\quad \# 25, \# 26, \# 27, \# 28, \\
\quad \# 34\end{array}$ \\
\hline $\begin{array}{l}\text { Task 3: } \\
\text { Planning a } \\
\text { project by } \\
\text { means of a } \\
\text { time } \\
\text { schedule }\end{array}$ & $\begin{array}{l}\text { The work packages of an } \\
\text { intrapreneurial project } \\
\text { (introduction of an } \\
\text { online shop) have to } \\
\text { be sequenced } \\
\text { (referring to a GANTT } \\
\text { chart) according to } \\
\text { their } \\
\text { interdependencies. As }\end{array}$ & $\begin{array}{l}\text { The participant creates a } \\
\text { GANTT chart using a } \\
\text { table tool that displays } \\
\text { all four work packages } \\
\text { and their } \\
\text { interdependencies in } \\
\text { the right order. }\end{array}$ & $\begin{array}{l}\text { SEQU, } \\
\text { INFO, } \\
\text { TERM }\end{array}$ & $\begin{array}{l}\# 5, \# 6, \# 7, \# 8, \# 9, \# 10 \text {, } \\
\quad \# 11, \# 15\end{array}$ \\
\hline
\end{tabular}


Table 1 (continued)

\begin{tabular}{|c|c|c|c|c|}
\hline \multicolumn{2}{|c|}{$\begin{array}{l}\text { Situational intrapreneurship challenges } \\
\text { among commercial apprentices }\end{array}$} & $\begin{array}{l}\text { Observable evidence } \\
\text { when solving the tasks } \\
\text { (response) }\end{array}$ & $\begin{array}{l}\text { Situation- } \\
\text { specific } \\
\text { skills* } \\
\text { (Fig. 1) }\end{array}$ & $\begin{array}{l}\text { Possible error types } \\
\text { according to Mumford } \\
\text { et al. } 2006^{* *}\end{array}$ \\
\hline \multirow[t]{2}{*}{ Task } & \multirow[t]{2}{*}{ Task description } & Referring to RQ1: & \multicolumn{2}{|c|}{ Referring to RQ2 } \\
\hline & & $\begin{array}{l}\text { Expected solution space } \\
\text { (objective norms set) }\end{array}$ & $\begin{array}{l}\text { Curricular } \\
\text { goals }\end{array}$ & $\begin{array}{l}\text { Which of the } 35 \text { error } \\
\text { types could occur, in } \\
\text { general? }\end{array}$ \\
\hline
\end{tabular}

an information base, the protocol of the last team meeting and the time schedule of the last project (e.g., GANTT chart) are provided.

Task 4:

Anticipating and estimating risks

Task 5:

Planning

and

monitoring

costs and profits

Task 6:

Coping

with

distur-

bances

\section{Because of the} introduction of the new online shop, ALUSIM faces changes within the distribution structure (it had been B2B, but now it is also B2C). It is asked how likely it is that one of the current dealers is making use of his exceptional right of termination.

\section{Management's} requirement for the online shop is that the project reaches break-even within 2.5 years. To check for that, the participant plans costs and profits within a given calculation (considering sales volumes, cost price, profit mark ups for the first 3 years, and investment costs). The participant now has to decide whether the project can be implemented or not.

The project was granted and is being implemented. An unexpected disturbance arises (shift in the market
The participant anticipates the risk that a current online dealer will make use of his exceptional right of termination due to the direct competition and proposes reasons for the possibility.

\section{Building on the}

completed break-even analysis (calculation of uncovered investment amount), the participant formulates an evidence-based decision. The project can be implemented, as it reaches breakeven within 2.5 years.
By reflecting on investments made and the given forecast, the participant decides that the project has to be continued.

\author{
RECO, \#1, \#2, \#3, \#4, \#5, \#6, \#8, \\ ANAL, \#9, \#10, \#11, \#12, \\ TERM, \#13, \#14, \#15, \#16, \\ DECI, \#17, \#18, \#19, \#21, \\ RISK, \#22, \#23, \#24, \#25, \\ DEFE \#26, \#27, \#28, \#29, \\ \#30, \#31, \#32, \#33 \\ \#34, \#35
}
INFO, $\quad \# 1, \# 2, \# 3, \# 4, \# 5, \# 6, \# 7$, DIST, \#8, \#9, \#10, \#11, \#12, REFL, \#13, \#14, \#15, \#16, DEFE \#17, \#18, \#19, \#21, \#22, \#23, \#24, \#25, \#26, \#27, \#28, \#29,


Table 1 (continued)

Situational intrapreneurship challenges among commercial apprentices

\section{Task}

Task description

\author{
Observable evidence \\ when solving the tasks \\ (response)
}

Referring to RQ1:

Expected solution space (objective norms set)
Situation- Possible error types specific according to Mumford skills* et al. 2006**

(Fig. 1)

Referring to RQ2

Curricular Which of the 35 error goals types could occur, in general?
launch of the
complemented
product). This shift is
associated with
changes in sales
opportunities for the
ALUSIM online shop.
This change has to be
evaluated by means of
a given calculation.

Furthermore, an evidence-based deci-

\#30, \#31, \#32, \#33,

sion is formulated. \#34, \#35

\begin{abstract}
*These linkages were determined based on the researchers' construction matrix and on prior studies of the project team (cf. Bley 2017; Weber et al. 2016; Wiethe-Körprich et al. 2017). **35 error types according to Mumford et al. (2006): \#1: satisficing, \#2: surface evaluation, \#3: a priori framing, \#4: premature case application, \#5: information discounting, \#6: discounting of anomalies, \#7: information availability, \#8: overemphasis on tangible facts, \#9: information salience, \#10: restricted information search, \#11: information accessibility, \#12: failure to explore unique causal relationships, \#13: failure to explore complex causal relationships, \#14: discounting alternative models, \#15: over-extended search, \#16: preservation of relationships, \#17: illusory correlation, \#18: concept over-determination, \#19: concept over-differentiation, \#20: inclusion of tangential concepts, \#21: isolation, \#22: limited elaboration, \#23: fixing, \#24: goal fixation, \#25: functional fixedness, \#26: means-end analysis, \#27: anchoring, \#28: insufficient idea analysis, \#29: rejection of risk, \#30: aversion to regret, \#31: over-optimism, \#32: over-analysis, \#33: failure to commit, \#34: confirmatory bias, \#35: estimation error
\end{abstract}

In a further step, we aligned our findings (RQ2). First, we matched the six openformat tasks and their associated bundles of situation-specific skills (Fig. 1, right side;

Table 2 Calculated task difficulties of the six open-format tasks analyzed

\begin{tabular}{lll}
$\begin{array}{l}\text { Task difficulty } \\
\text { calculated by item } \\
\text { response measures* }\end{array}$ & $\begin{array}{l}\text { Situational intrapreneurship challenge: } \\
\text { opportunity recognition (mean task } \\
\text { difficulty: }-.097)\end{array}$ & $\begin{array}{l}\text { Situational intrapreneurship challenge: } \\
\text { opportunity realization (mean task } \\
\text { difficulty: }-.374)\end{array}$ \\
\hline $\begin{array}{l}\text { Medium (corresponds } \\
\text { to mean value of } \\
\text { tasks) }\end{array}$ & $\begin{array}{c}\text { Task 2: Generating innovative business } \\
\text { ideas }\end{array}$ & $\begin{array}{l}\text { Task 3: Planning a project by means of a } \\
\text { time schedule }\end{array}$ \\
$\begin{array}{l}\text { High } \\
\text { Task 1: Perceiving opportunities and } \\
\text { risks }\end{array}$ & $\begin{array}{l}\text { Task 4: Anticipating and estimating risks } \\
\text { Task 5: Planning and monitoring costs } \\
\text { and profits } \\
\text { Task 6: Coping with disturbances }\end{array}$ \\
\hline
\end{tabular}

*Task difficulties were calculated according to item response measures, resulting in values on a logit scale. The range of task difficulties was then evenly divided into three sections (low, medium, high), and tasks were assigned to these sections 
Table 1) with the given responses with respect to the observed error categories. Additionally, we assigned the errors within those error categories to the 35 error types in accordance with Mumford et al. (2006). The alignments between the tasks and the skills could be made based on the researchers' construction matrix and prior studies of the project team (cf. Bley 2017; Bley et al. 2015; George et al. 2019; Weber et al. 2016; Wiethe-Körprich et al. 2017; Table 1). The assignment to the 35 error types was performed by two researchers independently, whereby the assignment to more than one error type was possible (Cohen's Kappa: $\kappa=.741$ ). As an example, we refer to task 1 . To show the expected response behavior, we assume that the apprentice is able to "recognize intrapreneurship challenges and opportunities (RECO)", "analyze intrapreneurship situations (ANAL)", and "use economic terms and routines (TERM)" (see Table 1 and Fig. 1). By adding our results, it is possible to associate typical domain-specific errors by applying these intrapreneurship-specific skills. For example, when apprentices analyze intrapreneurship situations (ANAL), they have problems assessing the consequences of a lack of qualified applicants in the VET labor market (error category 1, see also Table 3). Thereby, they often refer to the normal labor market and, consequently, fail to consider the unique features that arise in the recruitment and employment of apprentices for both applicants and organizations. This erroneous behavior corresponds to the error type "premature case application (\#4)" (Mumford et al. 2006) because the apprentices concentrate on the more common case model of "normal labor markets", although this ignores the particularities of the VET market. The complete alignment is depicted in Table 4. On the one hand, it specifies typical errors for intrapreneurial behavior of commercial apprentices (Hammond and Farr 2011), and on the other hand, it opens up a broader domain and its overarching discussion on errors in creative problem-solving processes (Mumford et al. 2006) (RQ2).

\section{Results}

With regard to RQ1 and considering the number of errors made for all included tasks, we found a large variation in the answers (referring to the extent and quality of wording). The quantitative overview, given in Table 3 (second column), demonstrates that the percentage of faulty responses varies. The primary challenges in task 5 "Planning and monitoring costs and profits" and task 6 "Coping with disturbances" (32.45\% and $38.63 \%$ erroneous answers, respectively) are managed best. In contrast, the challenges in task 1 "Perceiving opportunities and risks" and task 4 "Anticipating and estimating risks" most often entail faulty responses $(92.72 \%$ and $64.35 \%$ faulty answers, respectively). Overall, the aspects of opportunity realization (tasks 3-6; $\mathrm{M}_{\text {faulty }}$ answers $=46.30 \%$ ) yield faulty answers less often than the aspects of opportunity recognition (tasks 1 and 2; $M_{\text {faulty answers }}=69.32 \%$ ). This result is in line with the findings of Weber et al. (2016): task difficulties (calculated by item response measures; Winther et al. 2017) referring to opportunity recognition skills (tasks 1 and 2) show higher task difficulty values than tasks referring to the opportunity realization (tasks 3-6). In summary, it seems to be more challenging for commercial apprentices to cope with intrapreneurial situational demands regarding opportunity recognition than with those regarding opportunity realization. 
Table 3 Overview of the amount of faulty responses and patterns of errors (RQ1); $N=906$ apprentices responding to six open-format tasks (corresponding to 5436 responses overall). To be listed within the table, the error has to be coded at least once. Italics within the table indicate the most frequent errors that apprentices show regarding the task

\begin{tabular}{|c|c|c|c|c|}
\hline \multirow[t]{2}{*}{ Task } & \multirow{2}{*}{$\begin{array}{l}\text { Percentage } \\
\text { of faulty } \\
\text { answers } \\
(N=906)\end{array}$} & \multicolumn{3}{|l|}{ Overarching error category } \\
\hline & & $\begin{array}{l}\text { Error category 1: } \\
\text { Faulty intrapreneurial } \\
\text { awareness }\end{array}$ & $\begin{array}{l}\text { Error category 2: } \\
\text { Lacking tailored/ } \\
\text { evidence-based argu- } \\
\text { mentation }\end{array}$ & $\begin{array}{l}\text { Error category } 3 \text { : } \\
\text { Faulty use of economic/ } \\
\text { commercial routines } \\
\text { tools }\end{array}$ \\
\hline $\begin{array}{l}\text { (1) } \\
\text { Perceiving } \\
\text { opportuni- } \\
\text { ties and } \\
\text { risks }\end{array}$ & $92.72 \%$ & $\begin{array}{l}\text { The apprentice } \\
\text { misjudges the risks } \\
\text { that arise by } \\
\text { underestimating the } \\
\text { organizational } \\
\text { consequences and/or } \\
\text { overestimating the ap- } \\
\text { plicants' conse- } \\
\text { quences. }\end{array}$ & $\begin{array}{l}\text { - The apprentice does not } \\
\text { argue based on } \\
\text { commercial } \\
\text { terminology. }\end{array}$ & $\begin{array}{l}\text { - The apprentice does } \\
\text { not differentiate } \\
\text { between the various } \\
\text { job markets. }\end{array}$ \\
\hline $\begin{array}{l}\text { (2) Generating } \\
\text { innovative } \\
\text { business } \\
\text { ideas }\end{array}$ & $45.92 \%$ & $\begin{array}{l}\text { - The apprentice } \\
\text { addresses the wrong } \\
\text { target group within the } \\
\text { brainstormed } \\
\text { measures. } \\
\text { - The apprentice proposes } \\
\text { economically } \\
\text { unrealistic measures. }\end{array}$ & $\begin{array}{l}\text { - The brainstormed } \\
\text { measure is too vague. }\end{array}$ & \\
\hline $\begin{array}{l}\text { (3) Planning } \\
\text { a project } \\
\text { by means } \\
\text { of a time } \\
\text { schedule }\end{array}$ & $49.78 \%$ & & & $\begin{array}{l}\text { - The apprentice does not } \\
\text { use the GANTT chart } \\
\text { correctly. } \\
\text { - The apprentice does } \\
\text { not enter the work } \\
\text { packages into the } \\
\text { GANTT chart } \\
\text { correctly. }\end{array}$ \\
\hline $\begin{array}{l}\text { Anticipat- } \\
\text { ing and } \\
\text { estimating } \\
\text { risks }\end{array}$ & $64.35 \%$ & $\begin{array}{l}\text { - The apprentice refers to } \\
\text { economic variables } \\
\text { instead of the new } \\
\text { competition situation. } \\
\text { - The apprentice } \\
\text { misjudges the risks } \\
\text { that arise. } \\
\text { - The apprentice does not } \\
\text { understand the current } \\
\text { distribution situation. }\end{array}$ & $\begin{array}{l}\text { - The apprentice } \\
\text { marginalizes the risks. } \\
\text { - The apprentice shows } \\
\text { an emotional } \\
\text { argumentation. } \\
\text { - The apprentice does not } \\
\text { argue based on } \\
\text { commercial } \\
\text { terminology. }\end{array}$ & $\begin{array}{l}\text { - The apprentice does not } \\
\text { differentiate between } \\
\text { the various } \\
\text { distribution channels. } \\
\text { - The apprentice } \\
\text { misjudges the } \\
\text { competitive situation } \\
\text { that arises due to the } \\
\text { different distribution } \\
\text { channels. }\end{array}$ \\
\hline $\begin{array}{l}\text { (5) Planning } \\
\text { and } \\
\text { monitoring } \\
\text { costs and } \\
\text { profits }\end{array}$ & $32.45 \%$ & $\begin{array}{l}\text { The apprentice does not } \\
\text { derive the right } \\
\text { conclusions from the } \\
\text { break-even point anal- } \\
\text { ysis. }\end{array}$ & $\begin{array}{l}\text { - The apprentice does not } \\
\text { refer to } \\
\text { economic/commercial } \\
\text { conclusions from the } \\
\text { calculation to justify } \\
\text { his/her decision. } \\
\text { - The apprentice does not } \\
\text { refer to the } \\
\text { management's } \\
\text { requirements when }\end{array}$ & $\begin{array}{l}\text { - The apprentice cannot } \\
\text { interpret a calculation } \\
\text { for deriving a } \\
\text { decision. }\end{array}$ \\
\hline
\end{tabular}


Table 3 (continued)

\begin{tabular}{|c|c|c|c|c|}
\hline \multirow[t]{2}{*}{ Task } & \multirow{2}{*}{$\begin{array}{l}\text { Percentage } \\
\text { of faulty } \\
\text { answers } \\
(N=906)\end{array}$} & \multicolumn{3}{|l|}{ Overarching error category } \\
\hline & & $\begin{array}{l}\text { Error category 1: } \\
\text { Faulty intrapreneurial } \\
\quad \text { awareness }\end{array}$ & $\begin{array}{l}\text { Error category } 2 \text { : } \\
\text { Lacking tailored/ } \\
\text { evidence-based argu- } \\
\text { mentation }\end{array}$ & $\begin{array}{l}\text { Error category } 3 \text { : } \\
\text { Faulty use of economic/ } \\
\text { commercial routines/ } \\
\text { tools }\end{array}$ \\
\hline & & & $\begin{array}{l}\text { explaining his/her de- } \\
\text { cision. }\end{array}$ & \\
\hline $\begin{array}{l}\text { (6) Coping } \\
\text { with } \\
\text { distur- } \\
\text { bances }\end{array}$ & $38.63 \%$ & $\begin{array}{l}\text { - The apprentice does not } \\
\text { realize that by } \\
\text { stopping the } \\
\text { intrapreneurship } \\
\text { project, there are sunk } \\
\text { costs in any case. } \\
\text { - The apprentice misses } \\
\text { the complexity of the } \\
\text { resulting consequences } \\
\text { when stopping the } \\
\text { intrapreneurship } \\
\text { project. } \\
\text { - The apprentice } \\
\text { misjudges the risks } \\
\text { that arise when } \\
\text { stopping the } \\
\text { intrapreneurship } \\
\text { project. }\end{array}$ & $\begin{array}{l}\text { - The apprentice does not } \\
\text { formulate his/her own } \\
\text { argumentation but } \\
\text { copies the single } \\
\text { choice statement of a } \\
\text { prior task. } \\
\text { - The apprentice does not } \\
\text { refer to } \\
\text { economic/commercial } \\
\text { conclusions from the } \\
\text { calculation to justify } \\
\text { his/her decision. }\end{array}$ & $\begin{array}{l}\text { - The apprentice cannot } \\
\text { interpret a calculation } \\
\text { to derive a decision. }\end{array}$ \\
\hline
\end{tabular}

Going beyond quantitative performance scores and estimated task difficulties, by our inductive content analysis, we identified typical errors apprentices made when solving intrapreneurial challenges. Overall, we found three domain-specific error categories: "faulty intrapreneurial awareness", "lacking tailored/evidence-based argumentation", and "faulty use of economic/commercial routines/tools". A comprehensive overview of the identified error patterns in the particular tasks is displayed in Table 3. Addressing the faultiest task 1 "Perceiving opportunities and risks", the main challenge appears to be the differentiation of the various job markets (VET labor market vs. "normal" labor market). Another frequent error is that the apprentices misjudge the consequences for at least one of the two perspectives. Therefore, it is surprising that in particular, taking the applicant's perspective seems to be a challenge. In contrast, the adequate formulation of an argument by referring to commercial terminology can be found to be faulty, especially taking the organization's perspective. With regard to the least faulty task 5 "Planning and monitoring costs", apprentices make mistakes most often when they have to interpret the calculation as a foundation for a further decision-making process. Therefore, they often have problems with economic terms (e.g., "calendar quarter"). However, ignoring the economic value of such a project is a common mistake. Finally, the formulation of an evidence-based statement is challenging. Apprentices often do not refer to management's requirement or to any commercial categories at all.

As mentioned above, the errors found can be summarized in three categories (Table 2, columns 3-5): The first, faulty intrapreneurial awareness, addresses missed 
Table 4 Linkage between tasks, relevant skills (framed cells), and observed apprentice error categories (EC) and error types (\#1-35)

Linkage between tasks, relevant skills (framed cells), and observed apprentices' error categories (EC) and error types (\#1-\#35)

\begin{tabular}{|c|c|c|c|c|c|c|c|}
\hline & \multicolumn{3}{|c|}{$\begin{array}{l}\text { Situational intrapreneurship challenges } \\
\text { regarding opportunity recognition }\end{array}$} & \multicolumn{4}{|c|}{$\begin{array}{c}\text { Situational intrapreneurship challenges regarding } \\
\text { opportunity realization }\end{array}$} \\
\hline & 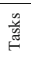 & $\begin{array}{l}\text { 1) Perceiving } \\
\text { opportunities and risks }\end{array}$ & $\begin{array}{l}\text { 2) Generating } \\
\text { innovative business } \\
\text { ideas }\end{array}$ & $\begin{array}{l}\text { 3) Planning a project } \\
\text { by means of a time } \\
\text { schedule }\end{array}$ & $\begin{array}{l}\text { 4) Anticipating and } \\
\text { estimating risks }\end{array}$ & $\begin{array}{l}\text { 5) Planning and } \\
\text { monitoring costs and } \\
\text { profits }\end{array}$ & $\begin{array}{l}\text { 6) Coping with } \\
\text { disturbances }\end{array}$ \\
\hline Task diffículty & & High & Medium & Medium & High & High & High \\
\hline \multicolumn{8}{|l|}{$\begin{array}{l}\begin{array}{l}\text { Situation- } \\
\text { specific skills } \\
\text { (cf. Figure 1) }\end{array} \\
\end{array}$} \\
\hline RECO & & EC3 (\#2, \#22) & & & $\mathrm{EC} 3(\# 2, \# 22)$ & & \\
\hline ANAL & & $\mathrm{EC} 1(\# 1, \# 4)$ & & & $\mathrm{ECl}(\# 1, \# 2)$ & & \\
\hline & & & $\mathrm{EC1}(\# 15, \# 16)$ & & & & \\
\hline IDEA & & & $\mathrm{EC} 2(\# 22, \# 23)$ & & & & \\
\hline CREA & & & $\mathrm{EC} 1(\# 17, \# 18)$ & & & & \\
\hline SEQU & & & & EC3 (\#9) & & & \\
\hline INFO & & & & EC3 (\#10) & & EC3 $(\# 8, \# 9, \# 10)$ & EC3 $(\# 8, \# 9, \# 10)$ \\
\hline TERM & & EC2(\#12,\#13,\#14) & & EC3 (\#12,\#13) & $\mathrm{EC} 2(\# 9, \# 22, \# 28)$ & & \\
\hline \multicolumn{8}{|l|}{ TOOL } \\
\hline DECI & & & & & EC3 $(\# 13, \# 18, \# 19)$ & $\mathrm{ECl}(\# 13)$ & \\
\hline RISK & & & & & EC1 $(\# 21, \# 31)$ & & \\
\hline \multicolumn{8}{|l|}{ TEAM } \\
\hline DIST & & & & & & & $\mathrm{ECl}(\# 26, \# 28)$ \\
\hline REFL & & & & & & & $\mathrm{EC1}(\# 21, \# 27)$ \\
\hline DEFE & & & & & EC2 (\#9, \#22) & EC2 (\#21, \#22, \#24) & $\mathrm{EC} 2(\# 22, \# 24)$ \\
\hline
\end{tabular}

Note. EC1 (bright grey): Faulty intrapreneurial awareness; EC2 (medium grey): Lacking tailored/evidencebased argumentation; EC3 (dark grey): Faulty use of economic/commercial routines/tools. Relevant error types (Mumford et al. 2006): \#1: satisficing, \#2: surface evaluation, \#4: premature case application, \#8: overemphasis on tangible facts, \#9: information salience, \#10: restricted information search, \#12: failure to explore unique causal relationships, \#13: failure to explore complex causal relationships, \#14: discounting alternative models, \#15: over-extended search, \#16: preservation of relationships, \#17: illusory correlation, \#18: concept over-determination, \#19: concept over-differentiation, \#21: isolation, \#22: limited elaboration, \#23: fixing, \#24: goal fixation, \#26: means-end analysis, \#27: anchoring, \#28: insufficient idea analysis, \#31: overoptimism

or misjudged intrapreneurship-specific content units and missed or misjudged projectspecific challenges. For example, referring to task 1 "Perceiving opportunities and risks", apprentices have immense problems with taking the perspective of a potential qualified applicant for an apprenticeship. They think, for example, that there are not a sufficient number of potential applicants, but do not see that the quality of potential applicants is problematized. Regarding task 5 "Planning and monitoring costs and profits", the apprentices do not derive the right decision from the calculated break-even point. Therefore, e.g., they do not recommend realizing the project, although the breakeven point is reached within the temporal target. Thus, an incorrect decision is made. Regarding this description, the error category can be understood as a knowledge-based error (Bauer 2008; Reason 1990). In essence, this first error category describes deviating behaviors that directly address the intrapreneurial process. Regarding RQ2, the found errors could be further described by the 35 error types of creative and innovative thinking (Mumford et al. 2006). For example, regarding the situational challenges that address opportunity recognition (task 1 and task 2), erroneous behavior is found where unique attributes of the situation are ignored in favor of more common case models (known as "premature case application (\#4)"). Additionally, errors that can be described by the term "satisficing (\#1)" dominate. That is, the developed measures are formulated vaguely or do not address the right target group. Considering the opportunity realization and its intrapreneurial challenges (task 3 to 6), apprentices make errors, for example, regarding their situational perceptions. In practice, so-called 
"satisficing (\#1)" and "surface evaluations (\#2)" are shown, meaning that more obvious attributes of the situation are considered, and an in-depth analysis is not conducted. However, the handling of solutions is sometimes problematic. Therefore, the solutions are looked at separately so that their consequences are not integrated into the overall situation ("isolation (\#21)"). Additionally, overly optimistic evaluations prevail over realistic assessments of the found solutions, especially when considering potential risks (“overoptimism (\#31)"). Additionally, an adaption of the decisions made according to new information appears to be hard ("anchoring (\#27)", "means-end analysis (\#26)").

Considering again RQ1, the second category includes errors regarding lacking tailored/ evidence-based argumentation: argumentation lines are built that are not adequate for the target group or that do not refer to calculations or other empirical results. Regarding this characterization, the error category can be associated with rule-based errors as well as knowledge-based errors. As it addresses mainly reasoning aspects, and therefore routines, it has to be associated with the former (Bauer 2008; Reason 1990). Nevertheless, when an argumentation within a new situation is necessary, higher cognitive demands arise, and a knowledge-based error is referred to (Bauer 2008; Reason 1990). Considering task 1, apprentices repeat the problem that there is a lack of qualified applicants for an apprenticeship or do not show why the qualified applicants have better chances now. Referring to RQ2, this error type would be associated to "failure to explore unique causal relationships (\#12)" because apprentices do not argue considering the unique features at hand but simply state a situation (Mumford et al. 2006). Referring to task 5 as another example, the apprentices, e.g., do not refer to their calculation results when arguing for or against, which corresponds to the error type of "limited elaboration (\#21)" (Mumford et al. 2006). Therefore, the apprentices may derive the right decision, but the quality of their argumentation is weak.

Last, the third overarching error category is called faulty use of economic/commercial routines/tools (RQ1). This means that the apprentices do not use a tool in the right way, such that errors occur. Task 1 builds on the economic principle of different job markets (VET labor market vs. "normal" market). Erroneous responses do not consider these differences and refer to employees in general or discuss the integration into employment after apprenticeship. With regard to RQ2, the error could be attributed to the error categories "surface evaluation (\#2)" and "limited elaboration (\#22)" because the tool of different job markets is not used to describe the situation (Mumford et al. 2006). For task 5, apprentices should gather information on the break-even point through calculation. One error is that the apprentice searches for the wrong date, so this error is associated with the error categories "overemphasis on tangible facts (\#8)", "information salience (\#9)", and "restricted information search (\#10)". Regarding a further characterization of those errors, they can be attributed to rule-based errors because they represent erroneous routines (Bauer 2008; Reason 1990).

Overall, not every overarching error category can be identified within every situational intrapreneurship challenge. Due to the task format, the errors of faulty intrapreneurial awareness or lacking tailored argumentation are not found for task 3 ("Planning a project by means of a time schedule"). Additionally, routines or tools are not required for task 2 ("Generating innovative business ideas").

Making more use of the identified errors for learning, a comprehensive linkage between tasks, relevant skill bundles, domain-specific error categories, and general error types were investigated. The resulting matrix is depicted in Table 4.

By this linkage, we see, e.g., for task 1, that the differentiation of job markets (VET labor market vs. "normal" labor market) appeared to be a main challenge. This faulty 
use of a commercial tool (EC3) can be associated with the recognition of intrapreneurial challenges and opportunities (RECO) as well as errors in problem construction by sticking to a "surface evaluation (\#2)" or idea generation through "limited elaboration (\#22)". The apprentices do perceive an intrapreneurial challenge (imbalance of supply and demand), but do not associate this imbalance to the right job market. Faulty intrapreneurial awareness (EC1) is assigned to the goal of perspective taking to analyze the perceived intrapreneurial challenge (ANAL, \#4). Within this error category, we see that the apprentices tend to under- or overestimate at least one of the two perspectives. As mentioned above, one example is that the apprentices argue that there is not a sufficient number of applicants at all. However, they do not recognize that not the quantity but the quality of potential apprentices is problematized. The lack of evidencebased argumentation (EC2) is matched with the skill to formulate an adequate statement on explored unique or complex relationships (TERM, \#12, \#13). We found that some apprentices do not reason at all but just state that the potential applicants have better chances. Concerning task 5, the main challenge that appeared was the interpretation of a calculation for further decision-making (EC3). The apprentices most often make a mistake when they should gather information on the date when the project will break even based on a calculation (INFO) that they do not seem to carry out correctly. This means that they might overemphasize tangible facts (\#8) or not organize or judge the found information (\#9). Thus, it is not surprising that they derive an incorrect decision from the calculation (EC1), which is associated with decision-making skills (DECI, \#13). Finally, the lack of evidence-based argumentation (EC2) refers to the skill of defending a (intrapreneurship) project (DEFE, \#21, \#24). Thereby, the apprentices do not refer to their calculation results or the management's expectations.

\section{Discussion, Limitations, and Future Prospects}

Entre-/intrapreneurial behaviors are demanded of all individuals to manage challenges within their work as well as private life (Baggen et al. 2016; Bacigalupo et al. 2016; Weber et al. 2014). Thereby, associated behaviors like problem construction, information gathering, or idea generation (also known as creative problem-solving; Mumford et al. 2006) are of relevance for all hierarchical levels of an enterprise (Kuratko et al. 2019). Most approaches in entre-/intrapreneurship education focus on correct performance in the sense of positive knowledge. In achievement assessments or course evaluations, mainly the achieved scores and estimated abilities and task difficulties are calculated. However, for fostering this decisive competence, it would be of great advantage to understand apprentices' errors to help them improve their performance (Mumford et al. 2006). The analysis of errors offers the chance to develop further approaches to train necessary competencies, including error management, or enable tailor-made guidance (Bauer et al. 2012; Hattie 2012; Oser and Volery 2012). As errors are understood as a deviation from a set of norms (Frese and Zapf 1994; Oser and Spychiger 2005), a domain-specific conceptualization is necessary (Gartmeier et al. 2015; Seifried et al. 2010; Wuttke and Seifried 2012). To address this, we accessed a scientific use file on an LSA ( $N=5346$ responses) obtained within a simulation on authentic work-related intrapreneurship challenges for apprentices in the field of industrial clerks (Weber et al. 2014, 2016). Referring to this scientific use file, we searched for errors within an interesting field: it is a German sample, whereby, in Germany, the 
prevalence rate of intrapreneurs is higher than the global mean value (Bosma et al. 2013). Additionally, empirical research showed that half of a youth cohort enter the dual apprenticeship system (Destatis \& WZB 2018), and apprentices do have a noteworthy impact on organizational innovation rates (Backes-Gellner and Rupietta 2014). Nevertheless, to yield compatible results and, therefore, results that are relevant-also for an international audience - we focused on the cross-sectional occupation of industrial clerks. Within an international comparison, it was shown that workplace tasks of industrial clerks are comparable to international workplaces within the commercial domain (Breuer et al. 2009; Deutscher and Winther 2017). Referring to an LSA for the analysis, it was possible to realize the advantages of a reliable and valid domain-specific measurement (DarlingHammond et al. 2013; Shavelson 2010).

Regarding our results, by our qualitative in-depth analysis, we could identify erroneous responses that vary in their quality and number. Considering the content level (RQ1), problems most often arise regarding the task of perceiving opportunities and risks. Estimating and monitoring costs and profits is managed best. Diving into more detail, we identified three overarching error categories: faulty intrapreneurial awareness (error category 1), lack of tailored/evidence-based argumentation (error category 2), and faulty use of economic/ commercial routines/tools (error category 3). There is no dominant error category; rather, the category depends on the field of action of the task. Furthermore, and referring to RQ2, the observed domain-specific errors could be associated with 35 more general error types (Mumford et al. 2006), such as "limited elaboration (\#4)", "means-end analysis (\#26)", and "anchoring (\#27)". This enables us to broaden the discussion to other domains but also gives more detailed hints on the effected cognitive processes. This represents important information for designing sufficient training, coaching, and instructional means. To the best of our knowledge, this is the first time that errors of commercial apprentices' intrapreneurship are identified and systematically synthesized in accordance with typical intrapreneurial challenges (Table 4).

This alignment can build a fruitful foundation for developing positive knowledge (the set norm) and negative knowledge ("what or how something is not" and "what not to do"; Gartmeier et al. 2008, 2011; Jonasson 2015; Minsky 1994; Oser and Spychiger 2005; Oser and Volery 2012; Parviainen and Eriksson 2006) and can be useful for teaching error management strategies and supporting students with tailored coaching measures. As learning from others' mistakes can yield a sufficient method for developing negative knowledge (Oser and Spychiger 2005; Oser et al. 2018), teachers are recommended to collect and integrate various learners' errors to develop negative knowledge that can provide learning experiences for a larger group of learners. However, practically, what would such instruction look like referring to our results? Considering the development of instructional means, we find that workplace learning in general faces challenges through complex, dynamic, and illstructured situations. A didactical model that explicitly addresses this point and tries, at the same time, to overcome problems of complex learning (e.g., isolated factual knowledge and cognitive load) is the four-component/instructional design (4C/ID; van Merriënboer and Kirschner 2018). This didactical model differentiates targeted learning input into four components (learning tasks, supportive information, procedural information, and part-task practice) while incorporating those components into complex learning arrangements to foster integrated learning (van Merriënboer and Kirschner 2013). A decisive advantage of this method is the active, self-reflective approach that also supports the development of negative knowledge (Bauer and Mulder 2007; van Merriënboer and Kirschner 2018). 
Different task formats enable two learning approaches that are recommended for developing negative knowledge: learning from others (e.g., through worked-out examples) and learning through one's own experiences (e.g., through conventional tasks). Through the so-called supportive information component within this 4C/ID model of van Merriënboer and Kirschner (2018), which aims at the construction of cognitive schemata, aspects such as "What is the concept?" (conceptual model), "How is the concept structured?" (structural model), and "How does the concept work?" (causal model) are directly addressed. The procedural information in this model is directed toward aspects of "How does one get started?" and the construction of cognitive rules. Finally, part-task practice is a component that is not mandatory but is sometimes necessary. It addresses procedural components that need to be available with a high level of automation because they are needed very often or are crucial for the success of a task.

Based on the identified error categories and error types associated with a situationspecific intrapreneurship skill, we obtain hints of the areas of intrapreneurship behavior that we must address in the teaching of intrapreneurship (when sensitizing for certain typical errors, supporting apprentices with strategies to prevent or overcome typical errors, e.g., by pushing them to think outside the box when facing the error type "surface evaluation (\#2)", or when developing negative knowledge). Referring to the 4C/ID, the following gives an example of how the four components (learning tasks, supportive information, procedural information, and part-task practice) of the didactical model can be used to address the identified errors. Concerning task 1, the differentiation of the various job markets (VET labor market vs. "normal" job market) is identified as the main challenge (EC3, \#2, \#22; Table 3). The recognition of an intrapreneurial challenge (RECO) can be assisted by the socalled supportive information component when different job markets (VET labor market vs. "normal" labor market) are introduced, by giving definitions for both markets by explicating the conceptual and structural model, highlighting differences between the two markets, and providing representative examples including variations for building a sophisticated mental model of the concept, by providing causal models presenting the relationships and interactions within the concept (e.g., the number of apprentices completing their apprenticeship every year has consequences for the number of people entering the "normal" job market). By applying procedural information, the apprentices are introduced to heuristics and error management strategies (e.g., analyzing and elaborating the problem situation at hand in more depth and breadth). Important facts or strategies can be routinized by so-called parttime-practice to internalize relevant concepts and strategies. To bring this knowledge into performance-related practice, different task formats can be used, ranging from "worked-out examples", where the apprentice can observe an expert in creative problem-solving intrapreneurship behavior, to imitating expert behavior or completion tasks, where apprentices must complete a task or even solve an open-ended task without any support. These four components should be integrated into a holistic complex problem to be solved (e.g., intrapreneurship project). Such a didactical approach enables not only the development of a tailored coaching for error management strategies, it also promotes the devlopment of declarative and procedural knowledge in the sense of positive and negative knowledge, referring to knowledge about "what or how something is or is not" and "what to do or not to do" (Gartmeier et al. 2008, Gartmeier et al. 2011; Jonasson 2015; Minsky 1994; Oser and Spychiger 2005; Oser and Volery 2012; Parviainen and Eriksson 2006).

Although the analyses yield a promising approach for identifying errors in the commercial apprentice intrapreneurship domain, one has to consider that the LSA used was 
developed primarily to assess intrapreneurial competence (in the sense of positive knowledge) and not negative knowledge. Furthermore, the selection of tasks limits the insights that could be gathered (Wuttke and Seifried 2012). Taking our findings and considering these limitations, the development of tasks that exclusively address negative knowledge could be a future project. Therefore, the open format of the chosen tasks should be emphasized as being especially useful because the errors found can be detected by self-formulated justifications (Bekkink et al. 2016), and the heuristics and strategies used can be related to high- or lowquality solutions. Additionally, we concentrated on German apprentices at the end of their three-year apprenticeship program. This seems to be necessary, as errors and negative knowledge have to be addressed in domain-specific conceptualizations (Wuttke and Seifried 2012). A comparison with other professions in future work can help build a baseline for a more overarching classification of common errors and negative knowledge in intrapreneurial behavior across other domains and other subareas within the domain of business, such as banking and retail.

\section{Funding Information Open Access funding provided by Projekt DEAL.}

Open Access This article is licensed under a Creative Commons Attribution 4.0 International License, which permits use, sharing, adaptation, distribution and reproduction in any medium or format, as long as you give appropriate credit to the original author(s) and the source, provide a link to the Creative Commons licence, and indicate if changes were made. The images or other third party material in this article are included in the article's Creative Commons licence, unless indicated otherwise in a credit line to the material. If material is not included in the article's Creative Commons licence and your intended use is not permitted by statutory regulation or exceeds the permitted use, you will need to obtain permission directly from the copyright holder. To view a copy of this licence, visit http://creativecommons.org/licenses/by/4.0/.

\section{References}

Achtenhagen, F. (2001). Criteria for the development of complex teaching-learning environments. Instructional Science, 29, 361-380.

Achtenhagen, F., \& Winther, E. (2009) Konstruktvalidität von Simulationsaufgaben: Computergestützte Messung berufsfachlicher Kompetenz - am Beispiel der Ausbildung von Industriekaufleuten. Bericht für das $B M B F$ [Construct validity of simulated tasks: technology-based measurement of vocation-specific competence - referring to the example of industrial clerks. Report for the German Federal Ministry of Education and Research]. Seminar für Wirtschaftspädagogik, Göttingen, Germany.

Achtenhagen, F., \& Winther, E. (2014). Workplace-based competence measurement: Developing innovative assessment systems for tomorrow's VET programmes. Journal of Vocational Education and Training, 66(3), 281-295.

Anselmann, V., \& Mulder, R. H. (2018). Learning from errors in insurance companies. Journal of Management Development, 37(2), 138-148.

Antoncic, B., \& Hisrich, R. D. (2001). Intrapreneurship: Construct refinement and cross-cultural validation. Journal of Business Venturing, 16(5), 495-527.

Aprea, C. (2013). Alltagsvorstellungen von Jugendlichen zu komplexen ökonomischen Phänomenen: Eine explorative Untersuchung am Beispiel der Wirtschafts- und Finanzkrise [Everyday ideas of young adults regarding complex economic phenomena: An explorative analysis by means of the economic and financial crisis]. In T. Retzmann (Ed.), Ökonomische Allgemeinbildung in der Sekundarstufe II [General education at secondary level] (pp. 100-112). Schwalbach im Taunus, Germany: Wochenschau-Verlag.

Bacigalupo, M., Kampylis, P., Punie, Y., \& Van den Brande, G. (2016). EntreComp: The entrepreneurship competence framework. Luxembourg: Publication Office of the European Union; EUR 27939 EN. https://doi.org/10.2791/593884. 
Backes-Gellner, U., \& Rupietta, C. (2014). Duale Berufsausbildung und innovation [dual vocational education and innovation]. Wirtschaft und Beruf, 6, 58-59.

Baethge, M., Achtenhagen, F., \& Arends, L. (2008). How to compare the performance of VET systems in skill formation. In K. U. Mayer \& H. Solga (Eds.), Skill formation. Interdisciplinary and cross-national perspectives (pp. 230-254). New York, NY: Cambridge University Press.

Baggen, Y., Lans, T., Biemans, H., Kampen, J., \& Mulder, M. (2016). Fostering entrepreneurial learning onthe-job: evidence from innovative small and medium-sized companies in Europe. European Journal of Education, 51(2), 193-209.

Bauer, J., \& Harteis, C. (2012). The ambiguity of errors for work and learning: Introduction to the volume. In J. Bauer \& C. Harteis (Eds.), Human Fallibiligy. The ambiguity of errors for work and learning (pp. 114). Cham, Switzerland: Springer.

Bauer, J., \& Mulder, R. H. (2007). Modelling learning from errors in daily work. Learning in Health and Social Care, 6(36), 121-133.

Bauer, J., Gartmeier, M., \& Harteis, C. (2010). Lernen aus Fehlern im Arbeitskontext: Lernprozesse, Lernergebnisse und förderliche Bedingungen [learning from errors at the workplace: Learning processes, learning outcomes, and fostering conditions]. Wirtschaftspychologie, 4(2010), 7-16.

Bauer, J., Gartmeier, M., \& Harteis, C. (2012). Human fallibility and learning from errors at work. In J. Bauer \& C. Harteis (Eds.), Human fallibility: The ambiguity of errors for work and learning (pp. 155-169). Dordrecht, The Netherlands: Springer.

Bauer, J. (2008) Learning from errors at work. Studies on nurses' engagement in error-related learning activities. Dissertation, University of Regensburg, Germany.

Bekkink, M. O., Donders, A. R. T., Kooloos, J. G., de Waal, R. M. W., \& Ruiter, D. J. (2016). Uncovering students' misconceptions by assessment of their written questions. MBC Medical Education, 16(1), 221.

Bley, S. (2017). Developing and validating a technology-based diagnostic assessment using the evidencecentered game design approach: An example of intrapreneurship competence. Empirical Research in Vocational Education and Training, 9(6), 1-32.

Bley, S., Wiethe-Körprich, M., \& Weber, S. (2015). Formen kognitiver Belastung bei der Bewältigung technologiebasierter authentischer Testaufgaben - Eine Validierungsstudie zur Abbildung von beruflicherKompetenz [forms of cognitive load when coping with technology-based authentic tasks A validation study regarding the instruction of vocational competence]. Zeitschrift für Berufs- und Wirtschaftspädagogik, 111(2), 268-294.

Blömeke, S., Gustafsson, J.-E., \& Shavelson, R. (2015). Beyond dichotomies. Competence viewed as a continuum. Zeitschrift für Psychologie, 223(1), 3-13.

Boon, J., der Klink, V., \& Janssen, J. (2013). Fostering intrapreneurial competencies of employees $m$ the educat1on sector. International Journal of Training \& Development, 17(3), 210-220.

Borza, A., \& Maier, V. (2012). The growing importance of intrapreneurship and its impact upon the survival of companies. Review of Management and Economic Engineering, 11(4), 13-22.

Bosma, N. \& Kelley, D. (2018). Global Entrepreneurship Monitor. 2018/2019 global report.

Bosma, N., Wennekers, S., Guerrero, M., Amorós, J.E., Martiarena, A. \& Singer, S. (2013). The Global Entrepreneurship Monitor. Special report on entrepreneurial employee activity.

Breuer, K., Hillen, S., \& Winther, E. (2009). Comparative international analysis of occupational tasks and qualification requirements for the labour market and assessment tasks at the end of VET in participating countries — Business and Administration. In M. Baethge \& L. Arends (Eds.), Feasibility study VET-LSA. A comparative analysis of occupational profiles and VET programmes in 8 European countries. International report. Göttingen, Germany: Soziologischen Forschungsinstitut.

Carmelo-Ordaz, C., Fernandez-Alles, M., Ruiz-Navarro, J., \& Soua-Ginel, E. (2012). The intrapreneur and innovation in creative firms. International Small Business Journal, 30(5), 513-535.

Cattaneo, A. A., \& Boldrini, E. (2017). You learn by your mistakes. Effective training strategies based on the analysis of video-recorded worked-out examples. Vocations and Learning, 10(1), 1-26.

Corbett, A., Covin, J. G., O’Connor, G., \& Tucci, C. L. (2013). Corporate entrepreneurship: State-of-the-art research and a future research agenda. Product Development and Management Association, 30(5), 812820 .

Darling-Hammond, L., Herman, J., Pellegrino, J., Abedi, J., Aber, J. L., Baker, E., Bennett, R., Gordon, E., Haertel, E., Hakuta, K., Ho, A., Linn, R. L., Pearson, P. D., Popham, J., Resnick, L., Schoenfeld, A. H., Shavelson, R., Shepard, L., Shulman, L., \& Steele, C. M. (2013). Criteria for high-quality assessments. Stanford, CA: Stanford Center for Opportunity Policy in Education, published with the Center for Research on Evaluation, Student Standards, and Testing (CRESST), UCLA, and the Learning Sciences Research Institute, University of Illinois at Chicago. 
de Jong, J. P. J., \& Marsili, O. (2015). The distribution of Schumpeterian and Kirznerian opportunities. Small Business Economics, 44(1), 19-35.

Deutscher, V. K., \& Winther, E. (2017). Instructional sensitivity in vocational education. Learning and Instruction, 53(1), 21-33.

Draxler, C. (2010). Sample size determination for Rasch model tests. Psychometrika, 75, 708-724.

Eisner, E. W. (1991). The enlightened eye: Qualitative inquiry and the enhancement of educational practice. New York, NY: Macmillan.

Eteläpelto, A., Vähäsantanen, K., Hökkä, P., \& Paloniemi, S. (2013). What is agency? Conceptualizing professional agency at work. Educational Research Review, 10, 45-65.

European Parliament and the Council [EU| (2006). Recommendation of the European Parliament and of the Council of 18 December 2006 on key competences for lifelong learning. Official Journal of the European Union, L394/310.

Federal Statistical Office [Destatis] \& Berlin Social Science Research Center Berlin [WZB] (2018). Datenreport 2018. Ein Sozialbericht für die Bundesrepublik Deutschland [Data report 2018. A social report for the Federal Republic of Germany]. Resource document. https://www.wzb. eu/system/files/docs/sv/iuk/dr2018_bf_pdf_ganzes_buch.pdf

Frank, H., Korunka, C., Lueger, M., \& Weismeier-Sammer, D. (2016). Intrapreneurship education in the dual education system. International Journal of Entrepreneurial Venturing, 8(4), 334-354.

Frese, M., \& Fay, D. (2001). Personal initiative: An active performance concept for work in the 21 st century. Research in Organizational Behavior, 23, 133-187.

Frese, M., \& Keith, N. (2015). Action errors, error management, and learning in organizations. Annual Review of Psychology, 66, 661-687.

Frese, M., \& Zapf, D. (1994). Action as the core of work psychology: A German approach. In H. C. Triandis, M. D. Dunnette, \& L. M. Hough (Eds.), Handbook of industrial and organizational psychology (pp. 271340). Palo Alto, CA: Consulting Psychologists Press.

Gartmeier, M. \& Schüttelkopf, E.M. (2012). Tracing outcomes of learning from errors on the level of knowledge. In J. Bauer \& C. Harteis (Eds.), Human fallibility (pp. 33-51). The ambiguity of errors for work and learning.

Gartmeier, M. \& Winkler, M. (2015). Lernen aus Fehlern und Eigeninitiative [Learning from errors and selfinitiative]. In M. Gartmeier, H. Gruber, T. Hascher, \& H. Heid (Eds.), Fehler. Ihre Funktion im Kontext individueller und gesellschaftlicher Entwicklung [Errors. Their function within the context of individual and social development] (pp. 283-297). Münster, Germany: Waxmann.

Gartmeier, M., Lehtinen, E., Gruber, H., \& Heid, H. (2011). Negative expertise: Comparing differently tenured elder care nurses' negative knowledge. European Journal of Psychology of Education, 26(2), 273-300.

Gartmeier, M., Bauer, J., Gruber, H., \& Heid, H. (2008). Negative knowledge: Understanding professional learning and expertise. Vocations and Learning, 1(3), 87-103.

Gartmeier, M., Gruber, H., Hascher, T., \& Heid, H. (2015). Fortschritte in der Fehlerforschung [Progresses within error research]. In M. Gartmeier, H. Gruber, T. Hascher, \& H. Heid (Eds.), Fehler. Ihre Funktion im Kontext individueller und gesellschaftlicher Entwicklung [Errors. Their function within the context of individual and social development] (pp. 7-14). Münster, Germany: Waxmann.

George, A. C., Bley, S., \& Pellegrino, J. (2019). Characterizing and diagnosing complex professional competencies - An example of intrapreneurship. Educational Measurement: Issues and Practice., 38(2), 89-100.

German Federal Ministry for Education and Research [BMBF] (2019). Berufsbildungsbericht [Federal report on Vocational Education and Training]. Resource document. https://www.bmbf.de/upload_ filestore/pub/Berufsbildungsbericht_2019.pdf.

Goodman, J., Wood, R., \& Chen, Z. (2011). Feedback specificity, information processing, and transfer of training. Organizational Behavior and Human Decision Processes, 115(2), 253-267.

von Graevenitz, G., Harhoff, D., \& Weber, R. (2010). The effects of entrepreneurship education. Journal of Economic Behavior and Organization, 76(1), 90-112.

Grohnert, T., Meuwissen, R. H. G., \& Gijselaers, W. H. (2018). Enabling young professionals to learn from errors - The role of supportive learning climate in crossing help network boundaries. Vocations and Learning. https://doi.org/10.1007/s12186-018-9206-2.

Hacker, W. (1986). Arbeitspsychologie: psychische Regulation von Arbeitstätigkeiten [Working psychology: psychological regulation of work behavior]. Bern, Switzerland: Huber.

Hacker, W. (2005). Allgemeine Arbeitspsychologie: psychische Regulation von Wissens-, Denk- und körperlicher Arbeit [General work psychology: psychological regulation of knowledge, thinking, and body work]. Bern, Switzerland: Huber. 
Hammond, M.M. \& Farr, J.L. (2011). The role of errors in the creative and innovation process. In Hofmann \& M. Frese (Eds.), Errors in organizations (pp. 67-96). Taylor \& Francis.

Harteis, C. (2018). Machines, change and work: An educational view on the digitalization of work. In C. Harteis (Ed.), The impact of digitalization in the workplace (pp. 1-10). Cham, CH: Springer.

Harteis, C., Bauer, J., \& Gruber, H. (2008). The culture of learning from mistakes: How employees handle mistakes in everyday work. International Journal of Educational Research, 47(4), 223-231.

Harteis, C., Bauer, J., \& Heid, H. (2012). Research on human fallibility and learning from errors at work. Challenges for theory, research and practice. In J. Bauer \& C. Harteis (Eds.), Human fallibility: The ambiguity of errors for work and learning (pp. 155-169). Dordrecht, The Netherlands: Springer.

Hattie, J. (2012). Visible learning for teachers: Maximizing impact on learning. London, UK: Routledge.

Heid, H. (2015). Über Relevanz und Funktion des Fehlerkriteriums [relevance and function of errors]. In M. Gartmeier, H. Gruber, T. Hascher, \& H. Heid (Eds.), Fehler. Ihre Funktion im Kontext individueller und gesellschafticher Entwicklung [errors. Their function within the context of individual and social development] (pp. 33-51). Waxmann: Münster, Germany.

Helmreich, R. L. (2000). On error management: lessons from aviation. Britisch Medical Journal, 320(7237), 781-785.

Hofmann, D. A., \& Frese, M. (2011). Errors, error taxonomies, error prevention, and error management: Laying the groundwork for discussing errors in organizations. In D. A. Hofmann \& M. Frese (Eds.), Errors in organizations (pp. 1-43). New York, NY: Routledge.

Ireland, R. D., Covin, J. G., \& Kuratko, D. F. (2009). Conceptualizing corporate entrepreneurship strategy. Entrepreneurship: Theory and Practice, 33(1), 19-46.

Jonasson, C. (2015). Interaction processes of handling errors in vocational schools: Students attending to changes in vocational practices. Vocations and Learning, 8(1), 75-93.

Kreuzer, C., Weber, S., Bley, S., \& Wiethe-Körprich, M. (2017). Measuring intrapreneurship competence as a manifestation of work agency in different educational settings. In M. Goller \& S. Paloniemi (Eds.), Agency at work (pp. 373-399). Cham, Switzerland: Springer.

Kuratko, D. F. (2009). The entrepreneurial imperative of the 21st century. Business Horizons, 52(5), 421-428.

Kuratko, D. F., Glodsby, M. G., \& Hornsby, J. F. (2019). Corporate innovation. Disruptive thinking in organizations. New York, NY: Routledge.

Kuratko, D. F., Ireland, R. D., Covin, J. G., \& Hornsby, J. S. (2005). A model of middle-level managers' entrepreneurial behaviour. Entrepreneurship Theory and Practice, 29(6), 699-716.

Madrid, H. P., Patterson, M. G., Birdi, K. S., Leiva, P. I., \& Kausel, E. E. (2014). The role of weekly highactivated positive mood, context, and personality in innovative work behavior: A multilevel and interactional model. Journal of Organizational Behavior, 35(2), 234-256.

Mayring, P. (2015). Qualitative Inhaltsanalyse: Grundlagen und Techniken [Qualitative content analysis: Foundations and techniques] (12th revised ed.). Weinheim, Germany: Beltz.

Messmann, G., \& Mulder, R. H. (2017). Proactive employees: The relationship between work-related reflection and innovative work behaviour. In M. Goller \& S. Paloniemi (Eds.), Agency at work. An agentic perspective on professional learning and development (pp. 141-159). Cham, Switzerland: Springer International Publishing AG.

Minnameier, G. (2008). Zur empirischen Analyse des Umgangs mit Fehlern im wirtschaftskundlichen Unterricht [Empirical analysis of handling errors in economic instruction]. In D. Münk, P. Gonon, K. Breuer and T. Deißinger (Eds.), Modernisierung der Berufsbildung. Neuere Forschungsstränge und Perspektiven der Berufs- und Wirtschaftspädagogik [Updating Vocational Education and Training. New research prospects and perspective of Human Resource Education and Training] (pp. 120-130). Opladen, The Netherlands: Barbara Budrich.

Minsky, M. (1994). Negative expertise. International Journal of Expert Systems, 71(3), 13-19.

Moriano, J. A., Molero, F., Topa, G., \& Levy Mangin, J. P. (2014). The influence of transformational leadership and organizational identification on intrapreneurship. International Entrepreneurship and Management Journal, 10(1), 103-119.

Mulder, M., \& Winterton, J. (2017). Introduction. In M. Mulder (Ed.), Competence-based vocational and professional education. Bridging the worlds of work and education (pp. 1-43). Cham, Switzerland: Springer International Publishing.

Mumford, M. D., Blair, C., Dailey, L., Leritz, L. E., \& Osburn, H. K. (2006). Errors in creative thought? Cognitive biases in a complex processing activity. Journal of Creative Behavior, 40(2), 75-109.

Oser, F., \& Spychiger, M. (2005). Lernen ist schmerzhaft. Zur Theorie des negativen Wissens und zur Praxis der Fehlerkultur. [Learning is hurting. The theory of negative knowledge and practice of error culture]. Weinheim, Germany: Beltz. 
Oser, F., \& Volery, T. (2012). "Sense of failure" and "sense of success" among entrepreneurs: The identification and promotion of neglected twin entrepreneur competencies. Empirical Research in Vocational Education and Training, 4(1), 27-44.

Oser, F., Mueller, S., Obex, T., Volery, T., \& Shavelson, R. J. (2018). Rescue an enterprise from failure: A revolutionary assessment tool for simulated performance. In O. Zlatkin-Troischanskaia, M. Toepper, H. A. Pant, C. Lautenbach, \& C. Kuhn (Eds.), Assessment of learning outcomes in higher education (pp. 123-144). Cham, Switzerland: Springer.

Parviainen, J., \& Eriksson, M. (2006). Negative knowledge, expertise and organisations. International Journal of Management Concepts and Philosophy, 2(2), 141-153.

Perlman, B., Gueths, J, \& Weber, D. A. (1988). The academic intrapreneur. Strategy innovation and management in Higher Education. NewYork: Praeger.

Pinchot, G. (1985). Intrapreneuring: Why you don't have to leave the corporation to become an entrepreneur. New York: Harper and Row.

Rasmussen, J. (1987a). Reasons, causes, and human error. In J. Rasmussen, K., Duncan, \& J. Leplat (Eds.), New technology an human error (pp. 293-301). Chichester, UK: Wiley.

Rasmussen, J. (1987b). The definition of human error and a taxonomy for technical system design. In J. Rasmussen (Ed.), New technology and human error (pp. 23-30). Chichester, UK: Wiley.

Rauch, A., \& Hulsink, W. (2015). Putting Entrepreneurship Education Where the Intention to Act Lies: An Investigation Into the Impact of Entrepreneurship Education on Entrepreneurial Behavior. Academy of Management Learning \& Education, 14(2), 1-18.

Rausch, A. (2012). Errors, emotions, and learning in the workplace - Findings from a diary study within VET. In E. Wuttke \& J. Seifried (Eds.), Learning from errors at school and at work (pp. 111-126). Opladen, Germany: Barbara Budrich.

Reason, J. (1987). A framework for classifying errors. In Rasmussen (Ed.), New technology and human error (pp. 5-14). Chichester, UK: Wiley.

Reason, J. (1990). Human error. Cambridge, UK: University Press.

Rebmann, K. (1996). Komplexität von Schulbüchern für das Fach Wirtschaftslehre [Complexity of schoolbooks for economics]. Unterrichtswissenschaft, 3, 267-284.

Sangmeister, J., Winther, E., Deutscher, V., Bley, S., Kreuzer, C., \& Weber, S. (2018). Designing competence assessment in VET for a digital future. In D. Ifenthaler (Ed.), Digital workplace learning (pp. 65-92). Cham, Switzerland: Springer.

Seifried, J., \& Wuttke, E. (2010). Student errors: How teachers diagnose them and how they respond to them. Empirical Research in Vocational Education and Training, 2(2), 147-162.

Seifried, J., Türling, J.M., \& Wuttke, E. (2010). Professionelles Lehrerhandeln - Schülerfehler erkennen und für Lernprozesse nutzen [Professional teacher behavior - Perceiving learners' errors and use them for learning processes]. In J. Warwas, and D. Sembill, (Eds.), Schulleitung zwischen Effizienzkriterien und Sinnfragen [School management between efficiency and sense making] (pp. 137-156). Baltmannsweiler, Germany: Schneider Verlag Hohengehren.

Senders, J. W., \& Moray, N. P. (1991). Human error. Cause, prediction, and reduction. Hillsdale, NJ: Erlbaum.

Shane, S. (2000). Prior knowledge and the discovery of entrepreneurial opportunities. Organization Science, 11(4), 448-469.

Shavelson, R. J. (2010). On the measurement of competency. Empirical Research in Vocational Education and Training, 2(1), 43-65.

Short, J. C., Ketchen, D. J., Shook, C. L., \& Ireland, R. D. (2010). The concept of "opportunity" in entrepreneurship research: Past accomplishments and future challenges. Journal of Management, 36(1), $40-65$.

Türling, J., Seifried, J., Wuttke, E., Gewiese, A., \& Kästner, R. (2011). "Typische” Schülerfehler im Rechnungswesenunterricht: Empirische Befunde einer Interviewstudie ["typical" studenterrors in accounting instruction: Empirical findings from an interview study]. Zeitschrift für Berufs-und Wirtschaftspädagogik, 107(3), 390-407.

Van Merriënboer, J. G., \& Kirschner, P. A. (2018). Ten steps to complex learning: A systematic approach to four-component instructional design (3rd ed.). London, UK: Routledge.

Van Merrienboer, J., \& Kirschner, Paul A. (2013). Ten steps to complex learning. A Systematic Approach to Four-Component Instructional Design, 2. Aufl. London, UK: Routledge.

Volery, T., Müller, S., Oser, F., Naepflin, C., \& del Rey, N. (2013). The impact of entrepreneurship education on human capital at upper-secondary level. Journal of Small Business Management, 51, 429-446.

Volpert, W. (1992). Wie wir handeln - was wir können [how we act - what we can do]. Heidelberg, Germany: Asanger. 
Weber S., Draxler, C., Bley, S., Wiethe-Körprich, M., Weiß, C., and Gürer, C. (2016). Der Projektverbund CoBALIT: Large Scale-Assessments in der kaufmännischen Berufsbildung - Intrapreneurship (CoBALIT) [The network CoBALIT: Large scale assessments in vocational education intrapreneurship]. In K. Beck, M. Landenberger, and F. K. Oser (Eds.), Technologiebasierte Kompetenzmessung in der beruflichen Bildung - Resultate aus dem Forschungsprogramm ASCOT [Technology-based competence measurement in vocational education - Results of the research initiative ASCOT] (pp. 75-92). Bielefeld: Bertelsmann.

Weber, S., \& Achtenhagen, F. (2017). Competence domains and vocational-professional education in Germany. In M. Mulder (Ed.), Competence-based vocational and professional education. Bridging the worlds of work and education (pp. 337-359). Cham, Switzerland: Springer International Publishing.

Weber, S., Trost, S., Wiethe-Körprich, M., Weiß, C., \& Achtenhagen, F. (2014). Intrapreneur: An entrepreneur within a company - An approach on modeling and measuring intrapreneurship competence. In S. Weber, F. K. Oser, F. Achtenhagen, M. Fretschner, \& S. Trost (Eds.), Becoming an entrepreneur (pp. 256-287). Rotterdam: Sense Publishers.

Weingardt, M. (2004). Fehler zeichnen uns aus. Transdisziplinäre Grundlagen zur Theorie und Produktivität des Fehlers in Schule und Arbeitswelt [Errors label us. Transdisciplinary foundations regarding the theory and productivity of errors at schools and in the workplace]. Bad Heilbrunn, Germany: Klinkhardt.

Weiß, C., \& Weber, S. (2016). Opportunity recognition as part of intrapreneurship competence - An analysis of exam essays of German industrial clerks. In E. Wuttke, J. Seifried, \& S. Schumann (Eds.), Economic competence and financial literacy of young adults. Status and challenges (pp. 165-192). Barbara Budrich: Opladen, Germany.

Wiethe-Körprich, M., Bley, S., Weber, S., \& Kreuzer, C. (2017). Intrapreneurship competence as an operationalization of work agency in professional contexts. In M. Goller \& S. Paloniemi (Eds.), Agency at work. An agentic perspective on professional learning and development (pp. 37-66). Cham, Switzerland: Springer International Publishing AG.

Winther, E., \& Achtenhagen, F. (2009). Measurement of vocational competencies - A contribution to an international large-scale assessment on vocational education and training. Empirical Research in Vocational Education and Training, 1(1), 88-106.

Winther, E., Seeber, S., Weber, S., Bley, S., Festner, D., Kreuzer, C., Rudeloff, M., Sangmeister, J., \& WietheKörprich, M. (2017). Modellierung und Messung beruflicher Kompetenzen in der kaufmännischen Domäne (CoBALIT) [Modelling and Measuring Vocational Competences in the Commercial Domain (CoBALIT)]. Version: 1. IQB - Institut zur Qualitätsentwicklung im Bildungswesen. Datensatz [Dataset]. https://doi.org/10.5159/IQB_CoBALIT_v1.

Wuttke, E., \& Seifried, J. (2012). Ansätze der Identifikation typischer Schülerfehler - Ergebnisse aus Studien in kaufmännischen Schulen. Unterrichtswissenschaft, 40, 174-192.

Publisher's Note Springer Nature remains neutral with regard to jurisdictional claims in published maps and institutional affiliations.

Christine Kreuzer studied Human Resource Education and Management at the Ludwig-MaximiliansUniversity, Munich from 2008 to 2013; since 2013, she has worked as a research and teaching assistant at the Institute of Human Resource Education and Management, Munich School of Management, LudwigMaximilians-University, Munich. She holds a Master of Business Research (MBR, 2015) and Dr. oec. Publ. (2018) from Ludwig-Maximilians-University in Munich. Modeling and measuring professional competencies represents her prior research interest.

Susanne Weber studied Human Resource Education and Management from 1985 to 1990 at Georg-August University, Göttingen; 1994 Dr. rer. Ppol.; senior researcher at Georg-August University, Göttingen; 2004 Habilitation at Humboldt University of Berlin; since 2005, Full Professor and Director of the Institute of Human Resource Education and Management, Munich School of Management, Ludwig-Maximilians-University, Munich. Her research interests are intercultural learning, entre- and intrapreneurship education, and modeling and measuring professional competencies. 